\title{
Benzoylecgonine Measurement
}

National Cancer Institute

\section{Source}

National Cancer Institute. Benzoylecgonine Measurement. NCI Thesaurus. Code C75350.

The determination of the amount of benzoylecgonine, the primary metabolite of cocaine, present in a sample. 